\title{
Promosi Kesehatan Kepada Orang Tua Mengenai Perilaku Hidup Bersih dan Sehat untuk Mencegah Hepatitis A pada Anak
}

\author{
Nyta Ellisa Muttaqin \\ Institut Ilmu Kesehatan Strada Indonesia \\ ellisanyta@gmail.com
}

\begin{abstract}
ABSTRAK
Anak-anak merupakan sosok individu yang sedang menjalani suatu proses perkembangan dengan sangat pesat dan sangat fundamental bagi kehidupan selanjutnya, anak sangat aktif, dinamis, antusias, dan hampir selalu ingin tahu seolah tidak pernah berhenti untuk belajar. Anak-anak akan cenderung melihat dan menerapkan hal-hal yang ia temui di lingkungan, termasuk kebiasaan dengan teman-teman sebayanya. Hal tersebut dapat menimbulkan beberapa masalah kesehatan, salah satunya terjangkit penyakit yang rute persebarannya lewat fecal-oral, yaitu hepatitis. Selain dari perilaku hidup bersih dan sehat yang buruk, penyebaran Hepatitis A ini sangat didukung oleh sanitasi lingkungan yang buruk. Berdasarkan data Riskesdas tahun 2018 di Indonesia sendiri tercatat $0,4 \%$ penduduknya terdiagnosis penyakit Hepatitis. Pemberian Pendidikan kesehatan dan promosi kesehatan pada orangtua dengan anak usia pra sekolah 4-6 tahun) dan usia sekolah tahun (6-12 tahun) adalah dengan peningkatan pengetahuan tentang pencegahan terjadinya suatu masalah penyakit di masyarakat. Selain itu untuk meningkatkan kesadaran masyarakat terhadap penyakit hepatitis dan cara penularannya. Pengetahuan orang tua tentang Hepatitis A dipengaruhi oleh tingkat usia, pendidikan, pekerjaan, dan sumber informasi.
\end{abstract}

Kata Kunci : Promosi kesehatan, Anak, Hepatitis A

\section{LATAR BELAKANG}

Anak-anak pada usia 4-6 tahun, dan 6-12 tahun seperti yang dapat kita perhatikan mereka cenderung sangat aktif dan sangat banyak berinteraksi dengan lingkungannya. Diperkuat oleh ungkapan Jean Piaget dan Lev Vygotsky yang menyatakan bahwa para ahli berpendapat anak bersifat aktif dan memiliki kemampuan untuk membangun pengetahuannya. Anak memperoleh pengetahuan dengan cara membangunnya sendiri secara aktif melalui interaksi dengan lingkungannya. Anak adalah makhluk yang 
belajar aktif yang dapat mengkreasi dan membangun pengetahuannya. Keaktifan dan keingintahuan anak tidak selalu menuntun kepada hal yang positif pada setiap aspek selain aspek pembelajaran karena anak dapat dikatakan baik dalam membangun pengetahuannya sendiri melalui apa yang ia temui di lingkungan sekitar, namun tidak dengan pembentukan persepsi utuh dan atau pembuatan keputusan.

Ragam kebiasaan anak-anak sering kali tidak terpantau oleh orang tua sehingga terjadi penyimpangan perilaku dari pola hidup bersih dan sehat yang seharusnya, diantaranya yaitu sering bertukar makanan pada saat makan bersama, alat makan yang digunakan pun sama, tidak mencuci tangan sebelum memakan sesuatu, jajan dari penjual yang tidak memperhatikan kebersihan bahan makanan atau cara pengolahannya maupun paparan lingkungan yang bisa mengkontaminasi makanan atau minuman yang dijualnya. Hal tersebut dapat menimbulkan beberapa masalah kesehatan, salah satu kasus paling umum ialah diare dan tidak menutup kemungkinan untuk terjangkit penyakit yang rute persebarannya lewat fecal-oral. Hepatitis A merupakan salah satu penyakit yang rute persebarannya lewat fecal-oral dan salah satu gejala awal dari penyakit ini ialah diare. Hepatitis A merupakan jenis hepatitis yang paling ringan dan paling mudah penularannya serta tidak menutup kemungkinan akan berubah atau masuk ke tingkat yang lebih parah seperti hepatitis B atau hepatitis $\mathrm{C}$ jika tidak dilakukan intervensi segera.

Dilansir dari website Departemen Kesehatan Indonesia bahwa pada tahun 2015, tepatnya minggu ke-2 pada bulan November 2015, telah terjadi kejadian luar biasa yaitu penyakit Hepatitis A yang menjangkit sebanyak 28 siswa mahasiswa IPB. Diketahui bahwa mahasiswamahasiswa tersebut tinggal di rumah kost sekitar kampus IPB Darmaga Bogor. Hasil dari investigasi tim memperkirakan sumber penularan Hepatitis A berasal dari rantai penyediaan pangan yang dikonsumsi masyarakat kampus IPB seperti kantin, penyedia makanan di salah satu unit asrama mahasiswa, dan suplai air minum dalam galon.

Kementerian Kesehatan telah mengidentifikasi 262 kasus hepatitis A di Depok, 171 orang di antaranya positif terinfeksi virus tersebut. Berdasarkan investigasi, perilaku tidak bersih office boy di SMPN 20 Depok lah yang menjadi penyebab penyebaran virus hepatitis A. (health.detik.com, 2019). Penularannya berupa mekanisme fecal-oral, dimana makanan yang dikonsumsi telah terkontaminasi oleh virus Hepatitis A baik melalui mulut orang lain yang terkontaminasi dan juga melaui feses. Dinyatakan bahwa perlu diperhatikan lagi mengenai perilaku hidup bersih dan 
sehat dari masyarakat, seperti kebersihan sumber makanan, tempat makanan, dan cara mencuci bahan makanan.

Dilansir dari Ikatan Dokter Anak Indoensia (IDAI) bahwa secara global sebanyak 1,4 juta kasus kesehatan disebabkan oleh Hepatitis A pada tahun 2015 dan banyak menjangkit anak-anak. Selain dari perilaku hidup bersih dan sehat yang buruk, penyebaran Hepatitis A ini sangat didukung oleh sanitasi lingkungan yang buruk. Didukung oleh karakteristik anak-anak yang cenderung aktif dan berinteraksi dengan lingkungannya. Maka dari itu, anak-anak memiliki kerentanan yang sangat tinggi untuk terjangkit Hepatitis A.

Dalam rangka mewujudkan derajat kesehatan yang optimal, berbagai upaya kesehatan telah diselenggarakan salah satu bentuk upaya kesehatan adalah pelayanan kesehatan Pemerintah dan Swasta. Pelayanan kesehatan melaksanakan program-programnya untuk meningkatkan derajat kesehatan masyarakat secara optimal salah satunya adalah pendidikan kesehatan. Pendidikan kesehatan identik dengan penyuluhan kesehatan karena keduanya berorientasi pada perilaku yang diharapkan yaitu perilaku sehat, sehingga mempunyai kemampuan mengenal masalah kesehatan dirinya, keluarga dan kelompoknya dalam meningkatkan kesehatannya (Marianti, 2016).

Rendahnya pengetahuan masyarakat tentang penyakit hepatitis A dan bagaimana penularan dari penyakit hepatitis A, serta kurangnya peran dari petugas kesehatan dalam memberikan promosi kesehatan membuat penyakit hepatitis terus saja terjadi di masyarakat. Adanya peningkatan pengetahuan seseorang setelah diberi promosi kesehatan (pendidikan kesehatan), karena dengan pemberian pendidikan kesehatan seseorang dapat memberikan informasi yang sebelumnya tidak diketahui (Marianti, 2016).

Untuk meningkatkan derajat kesehatan masyarakat, khususnya kepada anak-anak, perlu diadakannya suatu kegiatan pendidikan dan promosi kesehatan mengenai peningkatan perilaku hidup bersih dan sehat sebagai upaya mencegah penyakit Hepatitis A pada anak, dengan sasaran dari pendidikan dan promosi kesehatan ini adalah orangtua.

Alasan dari partisipan untuk kegiatan ini adalah orangtua, terutama ibu, memiliki peranan yang besar dalam mengelola makanan yang diperuntukkan kepada keluarga dan beberapa kebiasaan seperti mencuci tangan, mencuci bahan makanan, dan mencuci alat piring di rumah. Dengan diberikannya pendidikan dan promosi 
kesehatan kepada orangtua siswa, diharapkan orangtua siswa ini menjadi lebih waspada terhadap Hepatitis A pada anak, mampu menerapkannya dalam kehidupannya sehari-hari di rumah, mengedukasi anak-anaknya untuk menerapkan perilaku-perilaku sehat kepada anaknya, dan menyebarkan informasi yang sudah didapatkannya kepada anggota masyarakat lainnya, sehingga jika terjadi suatu kejadian yang tidak diinginkan dapat segera diberikan intervensi yang tepat, penyebaran dari kuman-kuman berbahaya seperti virus Hepatitis A ini dapat dicegah, dan dapat mengurangi jumlah penderita Hepatitis A.

\section{KASUS/MASALAH}

Bagaimana promosi kesehatan kepada orang tua mengenai perilaku hidup bersih dan sehat untuk mencegah hepatitis A pada anak?

\section{TINJAUAN PUSTAKA}

\section{Promosi Kesehatan dan Peran Pendidikan Kesehatan}

Menurut Green (Notoatmodjo, 2007), promosi kesehatan adalah segala bentuk kombinasi pendidikan kesehatan dan intervensi yang terkait dengan ekonomi, politik, dan organisasi, yang direncanakan untuk memudahkan perilaku dan lingkungan yang kondusif bagi kesehatan. Green juga mengemukakan bahwa perilaku ditentukan oleh tiga faktor utama yaitu : 1. Faktor predisposisi (predisposising factors), yang meliputi pengetahuan dan sikap seseorang. 2. Faktor pemungkin (enabling factors), yang meliputi sarana, prasarana, dan fasilitas yang mendukung terjadinya perubahan perilaku. 3. Faktor penguat (reinforcing factors) merupakan faktor penguat bagi seseorang untuk mengubah perilaku seperti tokoh masyarakat, undang-undang, peraturan-peraturan dan surat keputusan.

Menurut Lawrence Green (1984), promosi kesehatan adalah segala bentuk kombinasi pendidikan kesehatan dan intervensi yang terkait dengan ekonomi, politik, dan organisasi yang dirancang untuk memudahkan perubahan perilaku dan lingkungan yang baik bagi kesehatan. Pada dasarnya tujuan utama promosi kesehatan adalah untuk mencapai 3 hal, yaitu : 1) Peningkatan pengetahuan atau sikap masyarakat 2) Peningkatan perilaku masyarakat 3) Peningkatan status kesehatan masyarakat.

Berdasarkan rumusan WHO (1994), dalam Notoatmodjo (2007), strategi promosi kesehatan secara global terdiri dari tiga hal, yaitu : 1) Advokasi (advocacy) Advokasi adalah kegiatan untuk meyakinkan orang lain, agar orang lain tersebut membantu atau mendukung terhadap tujuan yang akan dicapai. Dalam konteks promosi kesehatan, 
advokasi adalah pendekatan kepada para pembuat keputusan atau penentu kebijakan di berbagai sektor, dan di berbagai tingkat, sehingga para pejabat tersebut dapat mendukung program kesehatan yang kita inginkan. 2) Dukungan sosial (social supporrt) Strategi dukungan sosial adalah suatu kegiatan untuk mencari dukungan sosial melalui tokoh-tokoh formal maupun informal. Tujuan utama kegiatan ini adalah agar tokoh masyarakat sebagai penghubung antara sektor kesehatan sebagai pelaksana program kesehatan dengan masyarakat penerima program kesehatan. Bentuk kegiatan dukungan sosial antara lain pelatihan-pelatihan para tokoh 10 masyarakat, seminar, lokakarya, bimbingan kepada tokoh masyarakat dan sebagainya. 3) Pemberdayaan masyarakat (empowerment) Pemberdayaan merupakan strategi promosi kesehatan yang ditujukan kepada masyarakat langsung. Tujuan utama pemberdayaan adalah mewujudkan kemampuan masyarakat dalam memelihara dan meningkatkan kesehatan untuk diri mereka sendiri. Bentuk kegiatan ini antara lain penyuluhan kesehatan, keorganisasian dan pengembangan masyarakat dalam bentuk koperasi, pelatihan-pelatihan untuk kemampuan peningkatan pendapatan keluarga (Notoatmodjo, 2007).

\section{Perilaku Hidup Bersih dan Sehat (PHBS)}

Perilaku Hidup Bersih dan Sehat adalah sekumpulan perilaku yang dipraktikan atas dasar kesadaran sebagai hasil pembelajaran yang menjadikan seseorang, keluarga, kelompok atau masyarakat mampu menolong dirinya sendiri (mandiri) di bidang kesehatan dan berperan aktif dalam mewujudkan kesehatan masyarakat (Depkes RI, 2011)

Menurut Depkes RI (2011), PHBS terdapat di dalam lima tatanan yang berhubungan antara satu dengan yang lain yaitu tatanan rumah tangga, tatanan institusi pendidikan, tatanan tempat kerja, tatanan tempat umum dan tatanan fasilitas kesehatan. Akan tetapi untuk melihat keberhasilan pembinaan PHBS, praktik PHBS yang diukur adalah yang dijumpai di tatanan rumah tangga.

\section{Hepatitis A}

Hepatitis A adalah penyakit hati yang disebabkan oleh virus hepatitis A.Virus ini menyebar terutama melalui ingests makanan atau air yang terkontaminasi dengan tinja orang yang terinfeksi. Penyakit ini sangat erat kaitannya dengan kurangnya penggunaan air bersih, sanitasi yang tidak memadai dan kebersihan pribadi yang buruk. Tidak seperti hepatitis B dan C, infeksi hepatitis A tidak menyebabkan penyakit hati kronis dan jarang berakibat fatal, tetapi dapat menyebabkan gejala yang 
melemahkan tubuh dan dapat menjadi hepatitis fulminan (gagal hati akut), yang berhubungan dengan kematian yang tinggi (WHO 2012)

Hepatitis A terjadi secara sporadis dan dalam epidemi di seluruh dunia, dengan kecenderungan untuk kambuh siklik. Setiap tahun ada sekitar 1,4 juta diperkirakan kasus hepatitis A di seluruh dunia (WHO 2012). Wabah terkait dengan makanan atau air yang terkontaminasi dapat meletus eksplosif, seperti epidemi di Shanghai pada tahun 1988 yang mempengaruhi sekitar 300.000 orang. Di Indonesia berdasarkan data yang berasal dari Departemen Kesehatan, hepatitis A masih merupakan bagian terbesar dari kasus - kasus hepatitis akut yang dirawat yaitu berkisar dari 39,8 - 68,3\%. Di beberapa daerah seperti Jakarta, Bandung, dan Makassar berkisar antara 35\%-45\% pada usia 5 tahun (Puspa R, 2011).

Hepatitis A disebabkan oleh Hepatitis-A Virus (HAV). Umumnya tidak sampai menyebabkan kerusakan jaringan hati. Mereka yang terinfeksi oleh virus ini, 99\% dapat pulih sepenuhnya. Virus HAV ini menular dengan cara fecal-oral (fecal: kotoran,/feses, oral: mulut). Artinya penyebaran dan penularan virus ini terjadi melalui kontaminasi makanan atau air oleh virus HAV yang terdapat pada kotoran/feses penderita Hepatitis A. Beberapa faktor risiko yang dapat meningkatkan penyebaran virus ini meliputi: sanitasi yang buruk, kontak langsung dengan pengidap, berbagi jarum suntik, berhubungan seks dengan pengidap, terutama seks anal, pria yang berhubungan seks dengan sesama pria, bekerja di area yang berhubungan dengan kotoran, misalnya selokan (Sari, 2008).

Penularan hepatitis A sering terjadi dari orang ke orang,. Virus ini menyebar melalui makanan atau air yang terkontaminasi dengan tinja orang yang terinfeksi. Selain itu hepatitis A dapat terjadi pada masyarakat yang : 1.Hygine dan sanitasi lingkungan, rendahnya kualitas sanitasi lingkungan dan adanya pencemaran terhadap sumber air atau makanan yang dikonsumsi banyak orang mempermudah terjadinya penularan dan kejadian luar biasa hepatitis A. Kebiasaan masyarakat yang kurang memperhatikan kebersihan lingkungan seperti BAB di sungai dapat meningkatkan penularan hepatitis A. Tinja yang terkontaminasi hepatitis A akan mencemari lingkungan lain. Seperti air, tanah dan lain-lain. 2.Ekonomi, tingkat sosial ekonomi masyarakat akan mempengaruhi ketersediaan air bersih dan perilaku hidup sehat serta kemampuan untuk menyediakan atau memberikan vaksinasi hepatitis A. Masyarakat dengan ekonomi sosial yang rendah pada umumnya jarang memperhatikan kualitas air yang di pakai dalam memenuhi kebutuhan sehari-hari. Air dengan kualitas yang buruk 
bisa saja terkontaminasi virus hepatitis A. Selain itu keluarga yang memiliki ekonomi sosial yang rendah pada umumnya memiliki tingkat pengetahuan rendah pula sehingga mereka tidak terlalu memikirkan betapa pentingnya pemberian vaksinasi hepatitis A. Sehingga hepatitis A dapat menular dengan cepat dari 1 orang ke oranglain. 3.Pola hidup bersih dan sehat merupakan hal yang sangat mempengaruhi penularan hepatitis A. Pola hidup bersih dan sehat yang rendah akan meningkatkan terjadinya penularan virus hepatitis tipe A tersebut. Hepatitis A dapat dengan cepat menular di tempat penitipan bayi, virus ini akan menular dengan cepat ketika si pengasuh bayi tidak mencuci tangan setelah mengganti popok bayi. Kesadaran mencuci tangan juga sangat penting dalam menangani penularan virus hepatitis. Kebiasaan buruk seperti berbagi makanan dan peralatan makan dengan penderita hepatitis A juga sebagai salah satu media penularan penyakit hepatitis A ini. 4. Gaya hidup di masyarakat juga merupakan salah satu faktor resiko terjadinya penyakit hepatitis. Kebiasaan memakan sayur mentah, seperti lalapan akan meningkatkan kemungkinan penularan penyakit hepatitis A. Bahan makanan seperti sayur yang terkontaminasi virus hepatitis A jika dikonsumsi virus tersebut akan berpindah kepada manusia. Virus tersebutkan menginfeksi manusia sehingga terjadi penyakit hepatitis (Aryana, 2015).

Masa inkubasi hepatitis A bervariasi antara 14-28 hari dengan gejala klinis yang juga bervariasi mulai dari asimtomatik hingga simtomatik, tergantung pada usia. Pada anak berusia $<6$ tahun, sekitar $70 \%$ kasus tidak menunjukkan gejala spesifik, sedangkan pada kasus dewasa sekitar $85 \%$ memperlihatkan gejala dan membutuhkan rawat inap. Gejala yang terjadi dapat berupa demam, tidak nafsu makan, diare, mual, rasa tidak nyaman di perut, kemih berwarna gelap, dan warna kuning pada kulit serta mata. Pada umumnya, gejala bertahan sekitar 2 bulan, tetapi pada kasus tertentu dapat melanjut hingga 6 bulan.

Menjaga kebersihan terhadap diri pribadi dan lingkungan sekitar tempat tinggal merupakan upaya awal yang sangat penting sebagai proses pencegahan lebih dini sebelum terjangkit atau mengalami resiko yang lebih tinggi terhadap serangan penyakit hepatitis. Selalu menjaga kebersihan dengan mengawali langkah yang mudah salah satunya dengan cara membiasakan diri untuk mencuci tangan sebelum dan sesudah menyentuh sesuatu.

\section{PEMBAHASAN}

Penyakit Hepatitis A dapat membawa konsekuensi ekonomi dan sosial yang signifikan di masyarakat. Proses penyembuhan penyakit hepatitis A memerlukan waktu dalam hitungan minggu atau bulan bagi seseorang agar dapat kembali bekerja, 
sekolah, dan melakukan aktivitas kehidupan sehari-hari. Dari segi ekonomi, dampaknya terhadap perusahaan makanan yaitu penurunan produktivitas lokal pada umumnya dan dapat menjadi masalah substansial. Penyakit hepatitis A merupakan penyakit yang mudah menular dan dapat menyerang banyak orang sehingga dapat menimbulkan wabah (Widodo, 2007). Hal ini disebabkan oleh kesehatan lingkungan yang kurang memadai, penyediaan air minum yang tidak memenuhi syarat, tingkat sosial ekonomi, tingkat pendidikan masyarakat (Harrison, 2005). Menurut WHO (Deinhart F, dkk, 1982) prevalensi Hepatitis dibagi pada tiga kategori, yaitu sebagai berikut: 1) Tinggi: di negara-negara berkembang dengan sanitasi yang sangat buruk dan perilaku personal hygiene yang kurang baik, risiko infeksi lebih besar dari 90\%. Sebagian besar infeksi terjadi pada anak usia dini dan mereka yang terinfeksi tidak memiliki gejala nyata. Wabah jarang karena anak-anak yang lebih tua dan orang dewasa umumnya kebal. Prevalensi penyakit di daerah seperti ini tergolong rendah dan jarang terjadi wabah. 2) Menengah: Di negara-negara berkembang, negara dengan ekonomi di daerah transisi di mana kondisi sanitasi sangat bervariasi. Ada daerah yang memiliki sistem sanitasi yang sudah memadai, namun juga ada yang masih kurang. Ironisnya, kondisi ekonomi yang terus membaik dan kesehatan dapat menyebabkan tingkat lebih tinggi dari penyakit, seperti infeksi terjadi pada kelompok usia lebih tua, dan wabah besar dapat terjadi (kejadian luar biasa). 3) Rendah: di negara maju dengan sanitasi yang baik dan kebersihan di tingkat infeksi rendah.

Penyakit hepatitis dapat terjadi pada remaja dan orang dewasa di kelompok berisiko tinggi seperti pengguna narkoba suntik, pria gay, orang yang bepergian ke daerah risiko tinggi dan populasi terisolasi, misalnya ditutup komunitas agama. Dari berbagai hasil penelitian nampak jelas bahwa Indonesia termasuk Intermediate Prevalence, bahkan pada daerah tertentu termasuk dalam kategori High Prevalence (Suwignjo, 1985). Hal ini dikarenakan sebagian provinsi di Indonesia, khususnya di Jawa, yang memiliki sistem sanitasi bervariasi, dan dengan kepadatan penduduk yang tinggi (memungkinkan untuk terjadinya wabah hepatitis A). Namun, di daerah lain, khususnya Indonesia timur, sistem sanitasi cenderung kurang baik, sementara kepadatan penduduknya rendah (wabah kepatitis A jarang terjadi). Dari segi kesehatan masyarakat, tingginya prevalensi Hepatitis virus ini merupakan indikasi bahwa sebetulnya ini merupakan masalah kesehatan masyarakat. Namun belum mendapat perhatian dari berbagai pihak, terutama di daerah-daerah, karena jarang menyebabkan kematian langsung. Hal ini mudah dilihat dari kurang tersedianya rekap 
data infeksi virus hepatitis A baik di tingkat puskesmas, rumah sakit, dan dinas kesehatan daerah dari tahun ke tahun.

Promosi kesehatan memberikan manfaat pada peserta, karena dengan mengetahui penyebab hepatitis bagi klien maka apabila ada anggota keluarga menderita penyakit yang sama, anggota keluarga dan klien siap menghadapi resiko terburuk dari penyakit hepatitis beserta komplikasinya. Dengan mengetahui tentang hepatitis A maka diharapkan klien mampu menyiapkan diri dengan pencegahan dan pengobatan yaitu: penyediaan makanan dan air bersih yang aman, sistem pembuangan sampah yang efektif, perhatikan higiene secara umum, mencuci tangan, pemakaian kateter, jarum suntik dan spuit sekali pakai serta selalu menjaga kondisi tubuh dengan sebaik-baiknya.

Hasil dari informasi pada tahap promosi kesehatan diharapkan klien melakukan dengan benar tahap pencegahan dan penurunan risiko penularan, seperti memberi penjelasan tentang hepatitis baik dari segi penyebab, tanda dan gejala, pengobatan, perawatan, penularan dan akibat yang didapat kalau pengobatan tidak dilakukan. Artinya bahwa pemberian pelayanan kesehatan melalui pendidikan yang tepat, maka komplikasi dapat dihindari.

Para pakar dan praktisi kesehatan yang berkecimpung di bidang hepatologi klinik, serta para pengelola pengendalian penyakit menular perlu bekerjasama bahumembahu dalam merumuskan langkah-langkah untuk menangani masalah ini. Baik dari aspek diagnostik, pencegahan, pengobatan, maupun promosi kesehatan. Perhatian tidak hanya perlu diberikan di tingkat lokal dan nasional melainkan juga di tingkat regional dan global (Dinas Kesehatan Indonesia, 2007).

Dalam pemeliharaan kesehatan yang utuh dibutuhkan peran yang beragam mulai dari keluarga guru, masyarakat, kader kesehatan maupun tokoh masyarakat lain. Karena jaminan kesehatan masyarakat adalah tanggungjawab bersama (Hendrawati, et.al, 2018; Rahayuwati et.al, 2018).

\section{KESIMPULAN}

Kegiatan pendidikan dan promosi kesehatan dapat teridentifikasi dari tingkat pengetahuan dan sikap partisipan selama mengikuti kegiatan pendidikan dan promosi kesehatan. Peningkatan pengetahuan dan perubahan sikap partisipan dapat ditunjukkan dari antusias dari semua partisipan ketika melakukan demonstrasi melakukan berbagai teknik sebagai upaya meningkatkan perilaku hidup bersih dan sehat. Partisipan memahami dengan baik terkait informasi mengenai Hepatitis A, baik 
dari dampak, gejala, cara penularan, dan upaya mencegahnya, partisipan diharapkan dapat menyebarluaskan informasi ini kepada sanak keluarga, tetangga, dan orang-orang di sekitar mereka dan dapat meningkatkan kesadaran masyarakat terhadap penyakit hepatitis dan cara penularannya.

\section{DAFTAR PUSTAKA}

Badan Penelitian dan Pengembangan Kesehatan Kementrian Kesehatan RI.

2019. Laporan Nasional Riskesdas 2018. Jakarta: Lembaga Penerbit

Balitbangkes.

Departemen Kesehatan (2007). Hepatitis Masalah Kesehatan Dunia. . Available at: www.depkes.go.id.

Gani, Dr.Rino. 2009. Memahami Hepatitis. http//gaya.tempo.co/read/news diakses pada 4 januari 2020.

Health.detik.com. 2019. Begini Kronologis Mewabahnya KLB Hepatitis A di Depok. https://health.detik.com/berita-detikhealth/d-4810489/begini-kronologis-mewaba hnya-klb-hepatitis-a-di-depok diakses pada 4 januari 2020.

Mansjoer, Arif. 2009. Ilmu Penyakit Dalam. Jakarta. Internal Publishing

Mardhiyah, A., Mediani, H. S., \& Rahayuwati, L. (2019). Promosi Kesehatan Kepada Orang Tua Mengenai Perilaku Hidup Bersih dan Sehat untuk Mencegah Hepatitis A pada Anak. Media Karya Kesehatan, 2(1).

Marianti. 2016. Pengertian Hepatitis diakses dari https://www.alodokter.com/hepat itis-a.html diakses pada 4 januari 2020.

Maryati. 2009. Pengaruh Pendidikan Kesehatan Terhadap Peningkatan Pengetahuan dan Sikap Keluarga Penderita Hepatitis. diakses dari http//www.surakarta.ac.id diakses pada 4 januari 2020.

Meta Herdiana, Sjamsul Arief, Bagus Setyoboedi. (2015). Mengenal Hepatitis A pada Anak. Indonesian Pediatric Society. Retrieved from www.idai.or.id/artikel/seputar-kesehatan-anak/mengenal-hepatitis-a-pada-anak diakses pada 4 januari 2020.

Notoatmodjo, S. 2011. Kesehatan Masyarakat Ilmu dan Seni. Jakarta: Rineka Cipta.

Puspa R. 2011.Pendekatan Diagnostik Dan Hepatitis Akut. Arjawinangun

Putri, Maretta. Hepatitis A. Journal (2008). Yogyakarta. Available at: eprints.undip.ac.id.

Rahayuwati, L., Nurhidayah, I., Ibrahim, K., \& Setyorini, D. (2018). Pendidikan dan Promosi Kesehatan tentang Pencegahan Penyakit Kanker melalui Pilihan Jajan 
pada Siswa-Siswi Sekolah Dasar serta mengenali Potensi Masyarakat dalam Peningkatan Kesehatan. Media Karya Kesehatan, 1(2).

WHO. (2005). Hepatitis A, Penyakit Bawaan Makanan. Available at: www.who.go.int.

WHO. (2018). Hepatitis A. World Health Organization. Retrieved from www.who.int/news-room/fact-sheets/detail/hepatitis-a diakses pada 4 januari 2020. 